\title{
The superwadeites: Elucidation of a structural family related to the Wadeite structure and prediction of $\mathrm{Cs}_{2} \mathrm{Ge}_{5} \mathrm{O}_{11}$
}

Gregory Morrison ${ }^{\dagger,}$, Vancho Kocevski ${ }^{\dagger}, \S$, Scott T. Misture ${ }^{\dagger, \|}$, Nicholas R. Spagnuolo ${ }^{\dagger, \star}$, Adrian T. Hines ${ }^{\dagger, \$}$, Theodore Besmann ${ }^{\dagger, \S}$, Hans-Conrad zur Loye ${ }^{*}, \dagger, \$$

${ }^{\dagger}$ Center for Hierarchical Wasteform Materials, Columbia, SC, 29208, United States

‡Department of Chemistry and Biochemistry, University of South Carolina, Columbia, SC, 29208, United States

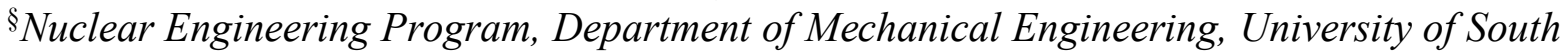
Carolina, Columbia, SC, 29208, United States

"Kazuo Inamori School of Engineering, Alfred University, Alfred, NY 14802, United States

*Corresponding author. E-mail: zurLoye@mailbox.sc.edu 


\section{Single Crystal X-ray Diffraction}

Single crystal X-ray diffraction data were collected on colorless plate crystals of $\mathrm{Cs}_{6} \mathrm{Ln}_{2} \mathrm{Ge}_{11} \mathrm{O}_{28}(\mathrm{Ln}=\mathrm{La}, \mathrm{Pr}, \mathrm{Nd})$. Each model was refined as a 2-component inversion twin consisting of 55.7(19)\%, 63.2(15)\%, and 63.0(17)\% of the major component for the $\mathrm{La}, \operatorname{Pr}$, and $\mathrm{Nd}$ analogues, respectively. The asymmetric unit consists of six cesium sites, six lanthanide sites, fifteen germanium sites, and thirty oxygen sites. As discussed in the manuscript, the structure is composed of $\mathrm{LnO}_{6}$ octahedra, $\mathrm{Ge}_{3} \mathrm{O}_{9}$ rings, and $\mathrm{Ge}_{2} \mathrm{O}_{7}$ dimers. The central oxygen in the $\mathrm{Ge}_{2} \mathrm{O}_{7}$ dimers is disordered across three symmetrically equivalent positions, each with an occupancy of $1 / 3$. A stable refinement was not achievable with the atomic displacement parameters of these central oxygens refined anisotropically, likely due to small electron density of the site and the close proximity between the disordered positions. For this reason, these sites were refined isotropically. As a result of the disordered central oxygen, disorder also exists within the other oxygens of the $\mathrm{Ge}_{2} \mathrm{O}_{7}$ unit. However, modeling these oxygens as split sites led to unreasonable bond distances, presumably due to further undetected disorder. For this reason, the other oxygens of the $\mathrm{Ge}_{2} \mathrm{O}_{7}$ units were modeled as a single, prolate sites.

Single crystal X-ray diffraction data were collected on a colorless shard of $\mathrm{Cs}_{12} \mathrm{Bi}_{3} \mathrm{Ge}_{24} \mathrm{O}_{58} \mathrm{~F}$. The selected shard was found to be a 2-component twin. The relevant twin law,

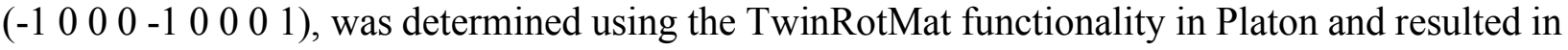
a major component that constitutes $64.78(7) \%$ of the crystal. The asymmetric unit consists of two bismuth sites, two cesium sites, six germanium sites, eleven oxygen sites, and a mixed oxygen/fluorine site. As discussed in the manuscript, the structure is composed of $\mathrm{BiO}_{6}$ octahedra, $\mathrm{Ge}_{3} \mathrm{O}_{9}$ rings, $\mathrm{Ge}_{2} \mathrm{O}_{7}$ dimers, $\mathrm{Ge}_{2} \mathrm{O}_{8}$ dimers, and $\mathrm{Ge}_{2} \mathrm{O}_{7} \mathrm{~F}$ dimers. The latter two of these share the same crystallographic sites. The central two atoms of the $\mathrm{Ge}_{2} \mathrm{O}_{8} / \mathrm{Ge}_{2} \mathrm{O}_{7} \mathrm{~F}$ dimers are each disordered across three symmetrically equivalent positions. If both of these sites are treated as solely oxygen sites, their occupancies freely refine to $28.3(17) \%$ and $34.8(18) \%$, close to the symmetry required occupancies of $1 / 3$. Oxygen and fluorine have very similar bonding environments and x-ray scattering factors making it difficult to distinguish them in crystallographic refinements. However, the presence of fluorine is necessitated by charge balance. We assigned the site with the larger freely refined occupancy as the half fluorine/half oxygen site. It is possible that it is the other site that is half fluorine/half oxygen or that each site is $1 / 4$ fluorine/3/4 oxygen. Due to the small mass percent fluorine in the structure $(0.39 \%)$ and the adjacency of Cs peaks, the presence of fluorine could not be confirmed via energy dispersive spectroscopy. Furthermore, the small size of the $\mathrm{Cs}_{12} \mathrm{Bi}_{3} \mathrm{Ge}_{24} \mathrm{O}_{58} \mathrm{~F}$ crystals and impure nature of the flux growth products inhibited obtaining a phase pure bulk sample for other elemental analysis methods. However, $\mathrm{Ge}_{2} \mathrm{O}_{7} \mathrm{~F}$ units were previously observed in $\mathrm{Cs}_{8} \mathrm{Dy}_{2} \mathrm{Ge}_{16} \mathrm{O}_{32} \mathrm{~F}_{2}$ supporting the presence of $\mathrm{Ge}_{2} \mathrm{O}_{7} \mathrm{~F}$ dimers in $\mathrm{Cs}_{12} \mathrm{Bi}_{3} \mathrm{Ge}_{24} \mathrm{O}_{58} \mathrm{~F}$. Along with the disorder in the $\mathrm{Ge}_{2} \mathrm{O}_{8} / \mathrm{Ge}_{2} \mathrm{O}_{7} \mathrm{~F}$ dimers, disorder also exists in the central oxygen of the $\mathrm{Ge}_{2} \mathrm{O}_{7}$ dimers. However, the splitting between the disordered positions was too small to obtain a stable refinement and therefore the site was modeled as a single oblate position. 


\section{$\mathrm{Cs}_{2} \mathrm{Ge}_{5} \mathrm{O}_{11}$ Single Crystal Synthesis}

In attempt to grow $\mathrm{Cs}_{3} \mathrm{TbGe}_{3} \mathrm{O}_{9}, 3 \mathrm{mmol}$ of $\mathrm{GeO}_{2}$ and $3 \mathrm{mmol}$ of $\mathrm{CsNO}_{3}(99.8 \%$, Alfa Aesar) were intimately ground, loaded into a covered alumina crucible, and heated to $600{ }^{\circ} \mathrm{C}$ for $12 \mathrm{~h}$ in attempt to decompose the nitrate. After heating, $1 / 2 \mathrm{mmol}$ of $\mathrm{Tb}_{2} \mathrm{O}_{3}$ (synthesized by reducing $\mathrm{Tb}_{4} \mathrm{O}_{7}$ under $5 \% \mathrm{H}_{2}$ in $\mathrm{N}_{2}$ at $800{ }^{\circ} \mathrm{C}$ for $12 \mathrm{~h}$ ) was added and the mixture was intimately ground, loaded into an alumina crucible, and sealed under vacuum in a fused silica tube. This reaction was heated to $750{ }^{\circ} \mathrm{C}$ for $12 \mathrm{~h}$. After heating the tube exhibited microcracks but retained a reduced pressure, indicating the generation of a partial pressure within the tube and the powder was a dark brown color, indicating partial oxidation of $\mathrm{Tb}$. Repeating this reaction with all grinding steps performed in a glovebox produced the same result. This indicated that $600{ }^{\circ} \mathrm{C}$ was not substantially high enough in temperature to completely decompose the $\mathrm{CsNO}_{3}$. Ultimately, we switched to $\mathrm{Cs}_{2} \mathrm{CO}_{3}$ for the solid-state synthesis of $\mathrm{Cs}_{3} \mathrm{TbGe}_{3} \mathrm{O}_{9}$.

Due to the visible failure of the nitrate solid state reactions, i.e. the brown color, these reactions remained unanalyzed until the writing of this manuscript and the $\mathrm{Cs}_{3} \mathrm{REGe}_{3} \mathrm{O}_{9}$ manuscript were in their final stages. Upon examination of the products by PXRD, the products were found to be $\mathrm{CsNO}_{3}, \mathrm{~Tb}_{7} \mathrm{O}_{12}$, and $\mathrm{Cs}_{2} \mathrm{Ge}_{5} \mathrm{O}_{11}$. Furthermore, despite no bulk melting of the powder during heating, small single crystals of $\mathrm{Cs}_{2} \mathrm{Ge}_{5} \mathrm{O}_{11}$ were present in the sample.

To better understand the process that led to the $\mathrm{Cs}_{2} \mathrm{Ge}_{5} \mathrm{O}_{11}$, we repeated the first step where $3 \mathrm{mmol}$ of $\mathrm{GeO}_{2}$ and $3 \mathrm{mmol}$ of $\mathrm{CsNO}_{3}$ were intimately ground, loaded into a covered alumina crucible, and heated to $600{ }^{\circ} \mathrm{C}$ for $12 \mathrm{~h}$. PXRD analysis, Figure S1, indicates the product to be a mixture of $\mathrm{CsNO}_{3}$ and $\mathrm{Cs}_{2} \mathrm{Ge}_{6} \mathrm{O}_{13}$. This suggests that the formation of $\mathrm{Cs}_{2} \mathrm{Ge}_{6} \mathrm{O}_{13}$ acts as a driving force for the partial decomposition of $\mathrm{CsNO}_{3}$. This product was then reground and heated to 750 ${ }^{\circ} \mathrm{C}$ for $12 \mathrm{~h}$ in an evacuated fused silica tube. PXRD analysis, Figure S2, indicates that the product remains predominately $\mathrm{CsNO}_{3}$ and $\mathrm{Cs}_{2} \mathrm{Ge}_{6} \mathrm{O}_{13}$ with only a small amount of $\mathrm{Cs}_{2} \mathrm{Ge}_{5} \mathrm{O}_{11}$. As $\mathrm{Cs}_{2} \mathrm{Ge}_{5} \mathrm{O}_{11}$ is more $\mathrm{Cs}$ rich than $\mathrm{Cs}_{2} \mathrm{Ge}_{6} \mathrm{O}_{13}$, this indicates that the elevated temperature led to a small amount of further $\mathrm{CsNO}_{3}$ decomposition, resulting in a small amount of $\mathrm{Cs}_{2} \mathrm{Ge}_{5} \mathrm{O}_{11}$. In contrast, when $\mathrm{Tb}_{2} \mathrm{O}_{3}$ is ground in before the second heating, the PXRD analysis, Figure S3, indicates that the products are primarily $\mathrm{CsNO}_{3}, \mathrm{~Tb}_{7} \mathrm{O}_{12}$, and $\mathrm{Cs}_{2} \mathrm{Ge}_{5} \mathrm{O}_{11}$ with no remaining $\mathrm{Cs}_{2} \mathrm{Ge}_{6} \mathrm{O}_{13}$. This suggests that the oxidation of $\mathrm{Tb}_{2} \mathrm{O}_{3}$, which occurs by reaction with $\mathrm{NO}_{3}{ }^{-}$, drives the decomposition of $\mathrm{CsNO}_{3}$ providing the $\mathrm{Cs}_{2} \mathrm{O}$ required to convert $\mathrm{Cs}_{2} \mathrm{Ge}_{6} \mathrm{O}_{13}$ to $\mathrm{Cs}_{2} \mathrm{Ge}_{5} \mathrm{O}_{11}$.

The above results suggest that $\mathrm{CsNO}_{3}$ is a good flux for the crystal growth of $\mathrm{Cs}_{2} \mathrm{Ge}_{5} \mathrm{O}_{11}$

but is not a good Cs source for its formation. Conversely, the solid-state reaction and $\mathrm{Cs}_{2} \mathrm{CO}_{3}$ flux growth reported in the manuscript indicate that $\mathrm{Cs}_{2} \mathrm{CO}_{3}$ is a good Cs source for the formation of $\mathrm{Cs}_{2} \mathrm{Ge}_{5} \mathrm{O}_{11}$ but is not a good flux for the formation of single crystals. This suggests that a mixture of $\mathrm{Cs}_{2} \mathrm{CO}_{3}$ and $\mathrm{CsNO}_{3}$ may be able to be used to form single crystals of $\mathrm{Cs}_{2} \mathrm{Ge}_{5} \mathrm{O}_{11}$ without the use of $\mathrm{Tb}_{2} \mathrm{O}_{3}$. However, when a ground sample of $\mathrm{Cs}_{2} \mathrm{Ge}_{5} \mathrm{O}_{11}$ and $\mathrm{CsNO}_{3}$ in a 1:3 molar ratio was heated to $650{ }^{\circ} \mathrm{C}$ for $48 \mathrm{~h}$, the only single crystals that formed were $\mathrm{Cs}_{2} \mathrm{Ge}_{6} \mathrm{O}_{13}$. This highlights the stability $\mathrm{Cs}_{2} \mathrm{Ge}_{6} \mathrm{O}_{13}$ in $\mathrm{CsNO}_{3}$ flux. 
Table S1 Crystallographic and SXRD refinement data for $\mathrm{Cs}_{12} \mathrm{Bi}_{3} \mathrm{Ge}_{24} \mathrm{O}_{58} \mathrm{~F}, \mathrm{Cs}_{6} \mathrm{Ln}_{2} \mathrm{Ge}_{11} \mathrm{O}_{28}(\mathrm{Ln}=\mathrm{La}, \mathrm{Pr}, \mathrm{Nd})$, and $\mathrm{Cs}_{2} \mathrm{Ge} 5 \mathrm{O}_{11}$

\begin{tabular}{|c|c|c|c|c|c|}
\hline Formula & $\mathrm{Cs}_{12} \mathrm{Bi}_{3} \mathrm{Ge}_{24} \mathrm{O}_{58} \mathrm{~F}$ & $\mathrm{Cs}_{6} \mathrm{La}_{2} \mathrm{Ge}_{11} \mathrm{O}_{28}$ & $\mathrm{Cs}_{6} \mathrm{Pr}_{2} \mathrm{Ge}_{11} \mathrm{O}_{28}$ & $\mathrm{Cs}_{6} \mathrm{Nd}_{2} \mathrm{Ge}_{11} \mathrm{O}_{28}$ & $\mathrm{Cs}_{2} \mathrm{Ge}_{5} \mathrm{O}_{11}$ \\
\hline Space group & $P-3$ & $P 3 c 1$ & $P 3 c 1$ & $P 3 c 1$ & $P 2_{1} / n$ \\
\hline$a(\AA)$ & $12.6937(4)$ & $12.9877(2)$ & $12.9334(6)$ & $12.9072(6)$ & $6.88690(10)$ \\
\hline$b(\AA)$ & $12.6937(4)$ & $12.9877(2)$ & $12.9334(6)$ & $12.9072(6)$ & $14.3530(3)$ \\
\hline$c(\AA)$ & $12.2555(4)$ & $35.7266(7)$ & $35.6609(17)$ & $35.5973(18)$ & $12.1755(3)$ \\
\hline$\beta$ & 90 & 90 & 90 & 90 & $90.9940(10)$ \\
\hline$V\left(\AA^{3}\right)$ & $1710.16(12)$ & $5218.99(19)$ & $5165.9(5)$ & $5135.8(5)$ & $1203.34(4)$ \\
\hline $\mathrm{Z}$ & 1 & 6 & 6 & 6 & 4 \\
\hline Crystal dimensions $\left(\mathrm{mm}^{3}\right)$ & $0.05 \times 0.05 \times 0.02$ & $0.05 \times 0.04 \times 0.02$ & $0.07 \times 0.03 \times 0.02$ & $0.06 \times 0.06 \times 0.02$ & $0.04 \times 0.02 \times 0.02$ \\
\hline Temperature $(\mathrm{K})$ & $301(2)$ & $301(2)$ & $301(2)$ & $301(2)$ & $302(2)$ \\
\hline Density $\left(\mathrm{g} \mathrm{cm}^{-3}\right)$ & 4.769 & 4.432 & 4.486 & 4.525 & 4.442 \\
\hline$\theta$ Range $\left(^{\circ}\right)$ & $2.489-36.345$ & $2.140-36.502$ & $2.284-36.312$ & $2.151-30.508$ & $2.194-30.500$ \\
\hline$\mu\left(\mathrm{mm}^{-1}\right)$ & 24.455 & 18.023 & 18.557 & 18.852 & 18.355 \\
\hline \multicolumn{6}{|c|}{ Data Collection and Refinement } \\
\hline Collected reflections & 104104 & 106969 & 147555 & 102993 & 53532 \\
\hline Unique reflections & 6313 & 10623 & 16715 & 10489 & 3673 \\
\hline $\mathrm{R}_{\text {int }}$ & 0.0373 & 0.0317 & 0.0332 & 0.0342 & 0.0459 \\
\hline $\mathrm{h}$ & $-21 \leq h \leq 21$ & $-18 \leq h \leq 18$ & $-18 \leq h \leq 21$ & $-18 \leq h \leq 18$ & $-9 \leq h \leq 9$ \\
\hline $\mathrm{k}$ & $-21 \leq k \leq 21$ & $-18 \leq k \leq 18$ & $-21 \leq k \leq 21$ & $-18 \leq k \leq 18$ & $-20 \leq k \leq 20$ \\
\hline 1 & $-20 \leq l \leq 19$ & $-51 \leq l \leq 51$ & $-59 \leq l \leq 59$ & $-50 \leq l \leq 50$ & $-17 \leq l \leq 17$ \\
\hline$\Delta \rho_{\max }\left(\mathrm{e} \AA^{-3}\right)$ & $7.734^{\mathrm{a}}$ & 2.053 & 2.575 & 2.230 & 2.339 \\
\hline$\Delta \rho_{\min }\left(\mathrm{e} \AA^{-3}\right)$ & -2.596 & -1.732 & -1.576 & -2.821 & -2.106 \\
\hline GoF & 1.053 & 1.125 & 1.063 & 1.094 & 1.128 \\
\hline Extinction coefficient & - & $0.000018(3)$ & $0.000038(4)$ & $0.000057(6)$ & $0.00076(4)$ \\
\hline Flack parameter & - & $0.443(19)$ & $0.368(15)$ & $0.370(17)$ & - \\
\hline${ }^{b} R_{1}(F)$ for $F_{o}^{2}>2 \sigma\left(F_{o}^{2}\right)$ & 0.0287 & 0.0273 & 0.0302 & 0.0230 & 0.0278 \\
\hline${ }^{\mathrm{c}} \mathrm{R}_{\mathrm{w}}\left(\mathrm{F}_{\mathrm{o}}^{2}\right)$ & 0.0750 & 0.0575 & 0.0625 & 0.0514 & 0.0518 \\
\hline
\end{tabular}

${ }^{a}$ This large residual density peak lies roughly at the center of the $\mathrm{Ge}_{2} \mathrm{O}_{2} / \mathrm{Ge}_{2} \mathrm{OF}$ central units of the $\mathrm{Ge}_{2} \mathrm{O}_{8} / \mathrm{Ge}_{2} \mathrm{O}_{7} \mathrm{~F}$ dimers. It is too close (1.247 $\AA$ ) to the $\mathrm{Ge} 4$ atom to be physically reasonable. It is there for believed to be an artifact of the data or the result of unaccounted for twinning.

${ }^{\mathrm{b}} \mathrm{R}_{1}=\Sigma|| \mathrm{F}_{0}|-| \mathrm{F}_{\mathrm{c}}|/ \Sigma| \mathrm{F}_{0} \mid$

${ }^{c} \mathrm{wR}_{2}=\left[\Sigma \mathrm{w}\left(\mathrm{F}_{\mathrm{o}}{ }^{2}-\mathrm{F}_{\mathrm{c}}{ }^{2}\right)^{2} / \Sigma \mathrm{w}\left(\mathrm{F}_{0}^{2}\right)^{2}\right]^{1 / 2} ; \mathrm{P}=\left(\mathrm{F}_{\mathrm{o}}{ }^{2}+2 \mathrm{~F}_{\mathrm{c}}{ }^{2}\right) / 3 ; w=1 /\left[\sigma^{2}\left(\mathrm{~F}_{\mathrm{o}}{ }^{2}\right)+(0.0379 \mathrm{P})^{2}+8.7549 \mathrm{P}\right]$ for the $\mathrm{Cs}_{12} \mathrm{Bi}_{3} \mathrm{Ge}_{24} \mathrm{O}_{58} \mathrm{~F} ; w=1 /\left[\sigma^{2}\left(\mathrm{~F}_{\mathrm{o}}{ }^{2}\right)+(0.00086 \mathrm{P})^{2}+50.5830 \mathrm{P}\right]$ for $\mathrm{Cs}_{6} \mathrm{La}_{2} \mathrm{Ge}_{11} \mathrm{O}_{28}, w=1 /\left[\sigma^{2}\left(\mathrm{~F}_{0}{ }^{2}\right)+(0.0125 \mathrm{P})^{2}+40.6600 \mathrm{P}\right]$ for $\mathrm{Cs}_{6} \mathrm{Pr}_{2} \mathrm{Ge}_{11} \mathrm{O}_{28}, w=1 /\left[\sigma^{2}\left(\mathrm{~F}_{\mathrm{o}}{ }^{2}\right)+(0.0132 \mathrm{P})^{2}+34.7077 \mathrm{P}\right]$ for $\mathrm{Css}_{6} \mathrm{Nd}_{2} \mathrm{Ge}_{11} \mathrm{O}_{28}$, and $w=1 /\left[\sigma^{2}\left(\mathrm{~F}_{0}{ }^{2}\right)+\right.$ $\left.(0.0100 \mathrm{P})^{2}+8.1540 \mathrm{P}\right]$ for $\mathrm{Cs}_{2} \mathrm{Ge}_{5} \mathrm{O}_{11}$ 
Table S2 Lattice parameters and atomic positions for $\mathrm{Cs}_{2} \mathrm{Ge}_{5} \mathrm{O}_{11}$, space group $P 2_{1} / n$, from the DFT refinement

\begin{tabular}{lllll}
\multicolumn{2}{l}{$a=7.1234 \AA$} & \multicolumn{2}{c}{$c=12.1049 \AA$} & $\beta$ \\
\hline Atom & Wyckoff site & $x$ & $y$ & $z$ \\
$\mathrm{Cs}(1)$ & $4 e$ & 0.7249 & 0.5520 & 0.9107 \\
$\mathrm{Cs}(2)$ & $4 e$ & 0.1906 & 0.5821 & 0.4148 \\
$\mathrm{Ge}(1)$ & $4 e$ & 0.5129 & 0.7445 & 0.6594 \\
$\mathrm{Ge}(2)$ & $4 e$ & 0.9522 & 0.7529 & 0.6091 \\
$\mathrm{Ge}(3)$ & $4 e$ & 0.6364 & 0.7374 & 0.4126 \\
$\mathrm{Ge}(4)$ & $4 e$ & 0.7237 & 0.9021 & 0.2508 \\
$\mathrm{Ge}(5)$ & $4 e$ & 0.7149 & 0.5883 & 0.2198 \\
$\mathrm{O}(1)$ & $4 e$ & 0.4531 & 0.6506 & 0.7393 \\
$\mathrm{O}(2)$ & $4 e$ & 0.4335 & 0.8523 & 0.6994 \\
$\mathrm{O}(3)$ & $4 e$ & 0.7575 & 0.7522 & 0.6935 \\
$\mathrm{O}(4)$ & $4 e$ & 0.1158 & 0.6661 & 0.6331 \\
$\mathrm{O}(5)$ & $4 e$ & 0.0604 & 0.8593 & 0.6044 \\
$\mathrm{O}(6)$ & $4 e$ & 0.8682 & 0.7267 & 0.4701 \\
$\mathrm{O}(7)$ & $4 e$ & 0.5862 & 0.8446 & 0.3537 \\
$\mathrm{O}(8)$ & $4 e$ & 0.5791 & 0.6472 & 0.3222 \\
$\mathrm{O}(9)$ & $4 e$ & 0.4701 & 0.7254 & 0.5156 \\
$\mathrm{O}(10)$ & $4 e$ & 0.6780 & 0.4837 & 0.1416 \\
$\mathrm{O}(11)$ & $4 e$ & 0.8273 & 0.5065 & 0.3260
\end{tabular}


Table S3 Lattice parameters, atomic positions, and atomic displacement parameters for $\mathrm{Cs}_{2} \mathrm{Ge}_{5} \mathrm{O}_{11}$, space group $P 2_{1} / n$, from the Rietveld refinement using the DFT structure as a starting model

\begin{tabular}{llllll}
\multicolumn{2}{l}{$a=6.94648(10) \AA$} & $b=14.3635(2) \AA$ & \multicolumn{2}{l}{$c=12.08993(16) \AA$} & $\beta=91.5188(7)^{\circ}$ \\
\hline Atom & Wyckoff site & $x$ & $y$ & $z$ & Biso \\
\hline $\mathrm{Cs}(1)$ & $4 e$ & $0.7378(7)$ & $0.5626(3)$ & $0.9260(5)$ & $2.80(6)$ \\
$\mathrm{Cs}(2)$ & $4 e$ & $0.2366(7)$ & $0.5618(3)$ & $0.4282(5)$ & $2.80(6)$ \\
$\mathrm{Ge}(1)$ & $4 e$ & $0.5292(6)$ & $0.7558(5)$ & $0.6882(3)$ & $1.18(6)$ \\
$\mathrm{Ge}(2)$ & $4 e$ & $0.9693(6)$ & $0.7517(6)$ & $0.6439(3)$ & $1.18(6)$ \\
$\mathrm{Ge}(3)$ & $4 e$ & $0.6683(5)$ & $0.7458(6)$ & $0.4430(3)$ & $1.18(6)$ \\
$\mathrm{Ge}(4)$ & $4 e$ & $0.7443(9)$ & $0.9002(4)$ & $0.2555(6)$ & $1.18(6)$ \\
$\mathrm{Ge}(5)$ & $4 e$ & $0.7302(10)$ & $0.5876(4)$ & $0.2602(6)$ & $1.18(6)$ \\
$\mathrm{O}(1)$ & $4 e$ & $0.503(3)$ & $0.6269(16)$ & $0.7262(17)$ & 1 \\
$\mathrm{O}(2)$ & $4 e$ & $0.432(3)$ & $0.8340(14)$ & $0.7761(18)$ & 1 \\
$\mathrm{O}(3)$ & $4 e$ & $0.769(3)$ & $0.7768(16)$ & $0.7282(16)$ & 1 \\
$\mathrm{O}(4)$ & $4 e$ & $0.178(3)$ & $0.6923(15)$ & $0.6646(17)$ & 1 \\
$\mathrm{O}(5)$ & $4 e$ & $0.026(3)$ & $0.8740(15)$ & $0.668(2)$ & 1 \\
$\mathrm{O}(6)$ & $4 e$ & $0.899(2)$ & $0.7622(18)$ & $0.5010(14)$ & 1 \\
$\mathrm{O}(7)$ & $4 e$ & $0.601(3)$ & $0.8453(17)$ & $0.365(2)$ & 1 \\
$\mathrm{O}(8)$ & $4 e$ & $0.663(3)$ & $0.6340(19)$ & $0.390(2)$ & 1 \\
$\mathrm{O}(9)$ & $4 e$ & $0.489(2)$ & $0.7305(17)$ & $0.5486(14)$ & 1 \\
$\mathrm{O}(10)$ & $4 e$ & $0.822(3)$ & $0.5068(19)$ & $0.1610(18)$ & 1 \\
$\mathrm{O}(11)$ & $4 e$ & $0.878(3)$ & $0.4870(15)$ & $0.3201(19)$ & 1
\end{tabular}


Table S4 Lattice parameters, atomic positions, and atomic displacement parameters for $\mathrm{Cs}_{2} \mathrm{Ge}_{5} \mathrm{O}_{11}$, space group $P 2_{1} / n$, from the Rietveld refinement using the single crystal structure as a starting model

\begin{tabular}{|c|c|c|c|c|c|}
\hline$a=6.8$ & $52(6) \AA$ & $14.36576(1)$ & $c=12.183$ & $35(10) \AA$ & $90.9972(5)^{\circ}$ \\
\hline Atom & Wyckoff site & $x$ & $y$ & $z$ & Biso \\
\hline $\operatorname{Cs}(1)$ & $4 e$ & $1.0059(3)$ & $0.56317(15)$ & $0.34343(17)$ & $2.04(6)$ \\
\hline $\operatorname{Cs}(2)$ & $4 e$ & $0.5247(3)$ & $0.43859(15)$ & $0.15383(18)$ & $2.69(6)$ \\
\hline $\mathrm{Ge}(1)$ & $4 e$ & $0.7002(3)$ & $0.2421(3)$ & $0.91294(19)$ & 0.6601 \\
\hline $\mathrm{Ge}(2)$ & $4 e$ & $0.5469(4)$ & $0.2543(3)$ & $0.66970(19)$ & 0.6443 \\
\hline $\mathrm{Ge}(3)$ & $4 e$ & $0.7499(4)$ & $0.2402(3)$ & $0.36372(19)$ & 0.6553 \\
\hline $\mathrm{Ge}(4)$ & $4 e$ & $0.5145(5)$ & $0.0948(2)$ & $0.5036(3)$ & 0.6482 \\
\hline $\operatorname{Ge}(5)$ & $4 e$ & $0.4924(5)$ & $0.4077(2)$ & $0.4750(3)$ & 0.7414 \\
\hline $\mathrm{O}(1)$ & $4 e$ & 0.7505 & 0.1243 & 0.9343 & 1.429 \\
\hline $\mathrm{O}(2)$ & $4 e$ & 0.8327 & 0.3061 & 1.0062 & 1.176 \\
\hline $\mathrm{O}(3)$ & $4 e$ & 0.7182 & 0.2796 & 0.7769 & 1.05 \\
\hline $\mathrm{O}(4)$ & $4 e$ & 0.3176 & 0.2729 & 0.7241 & 1.279 \\
\hline $\mathrm{O}(5)$ & $4 e$ & 0.6193 & 0.3365 & 0.5746 & 1.263 \\
\hline $\mathrm{O}(6)$ & $4 e$ & 0.597 & 0.1391 & 0.6356 & 1.066 \\
\hline $\mathrm{O}(7)$ & $4 e$ & 0.3282 & 0.0109 & 0.4771 & 1.09 \\
\hline $\mathrm{O}(8)$ & $4 e$ & 0.6419 & 0.1341 & 0.388 & 1.508 \\
\hline $\mathrm{O}(9)$ & $4 e$ & 0.9538 & 0.2498 & 0.4483 & 2.274 \\
\hline $\mathrm{O}(10)$ & $4 e$ & 0.595 & 0.3342 & 0.3619 & 2.006 \\
\hline $\mathrm{O}(11)$ & $4 e$ & 0.5986 & 0.5089 & 0.4183 & 1.342 \\
\hline
\end{tabular}




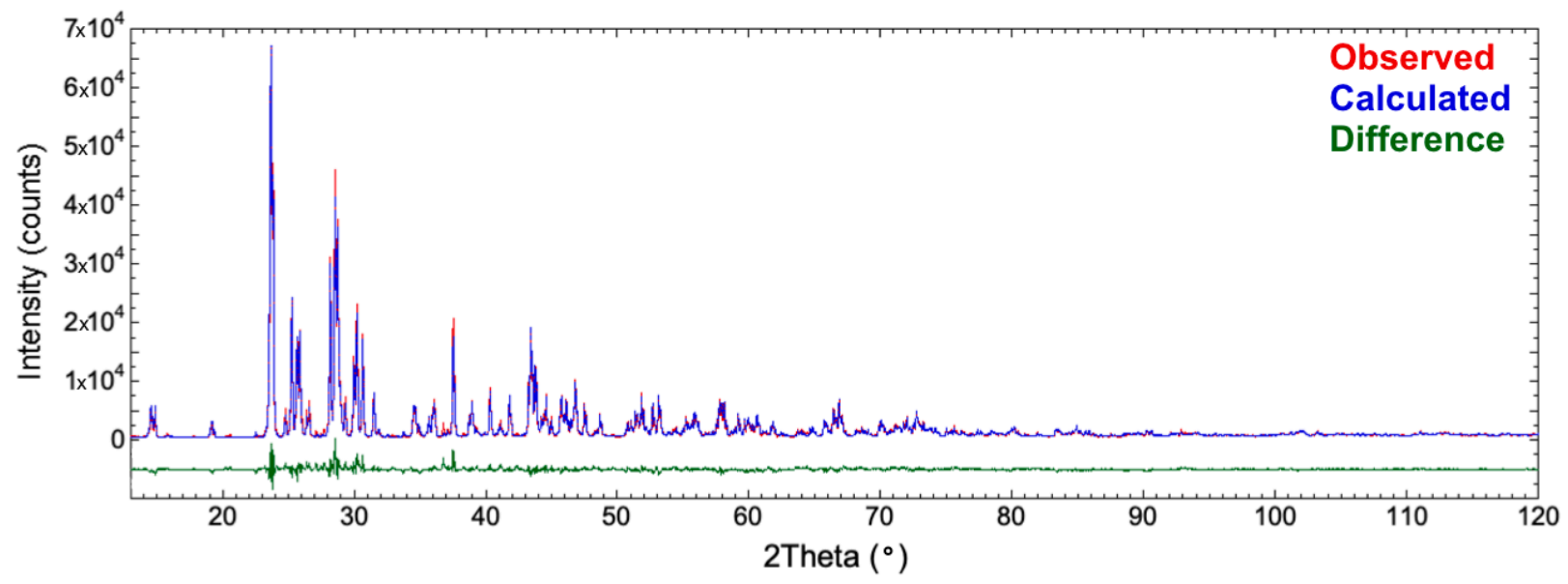

Figure S1. Rietveld refinement for $\mathrm{Cs}_{2} \mathrm{Ge}_{5} \mathrm{O}_{11}$ using the DFT structure as a starting model. The difference pattern is offset by -5000 counts for easier viewing. 


\section{SXRD}

a)

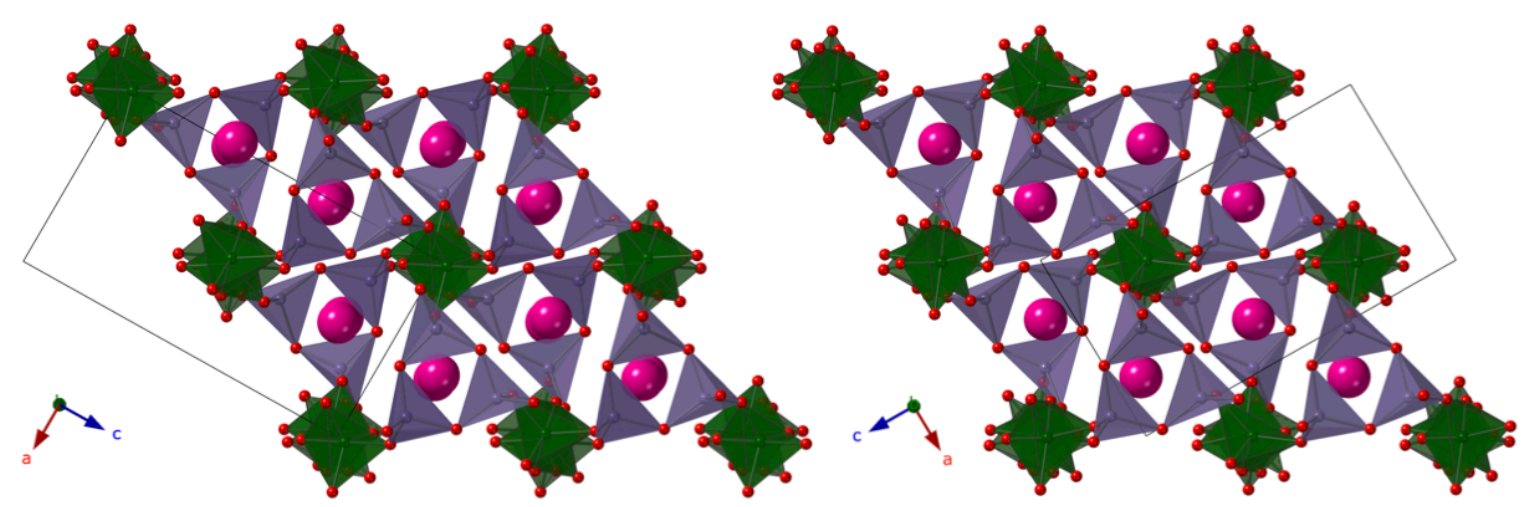

b)
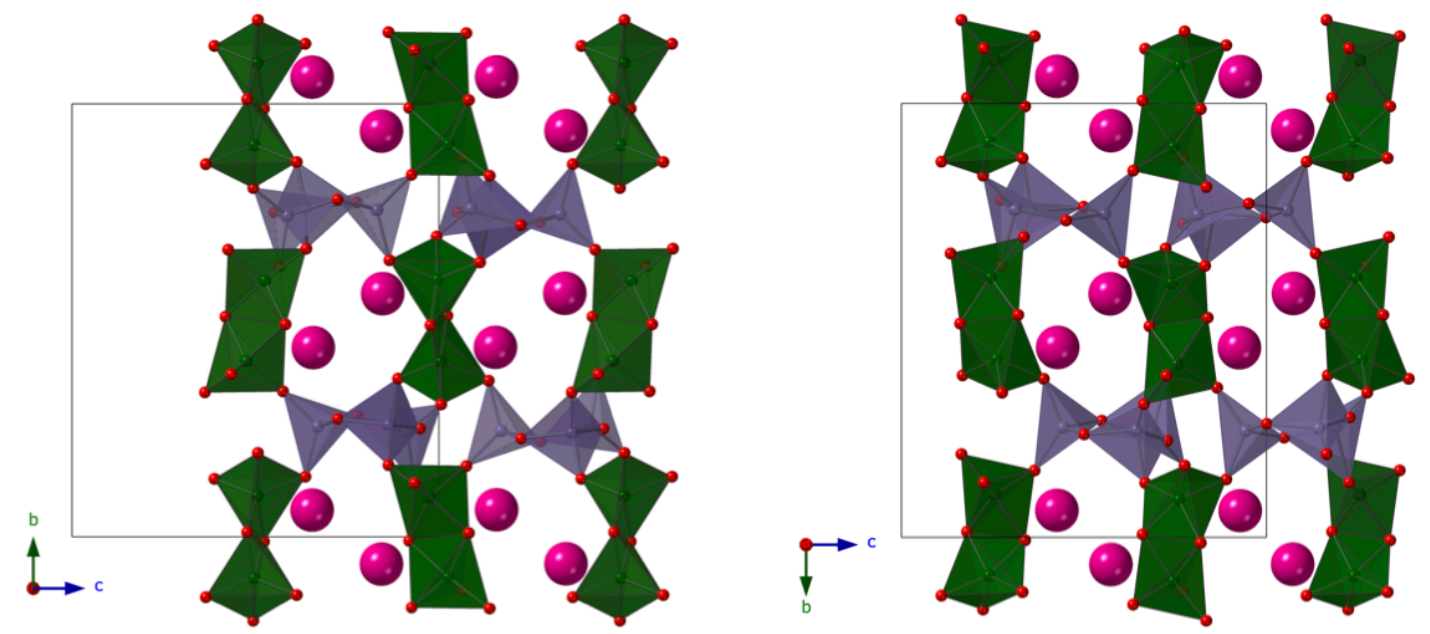

Figure S2. Structure of $\mathrm{Cs}_{2} \mathrm{Ge}_{5} \mathrm{O}_{11}$ as refined from SXRD data (left) and by Rietveld analysis of PXRD data (right) showing a) the view down the $b$-axis and c) the view down the $a$-axis. $\mathrm{GeO}_{4}$ polyhedra are shown in grey, $\mathrm{GeO}_{5}$ polyhedra in green, $\mathrm{Cs}$ atoms in pink, and oxygen atoms in red. 


\section{SXRD}
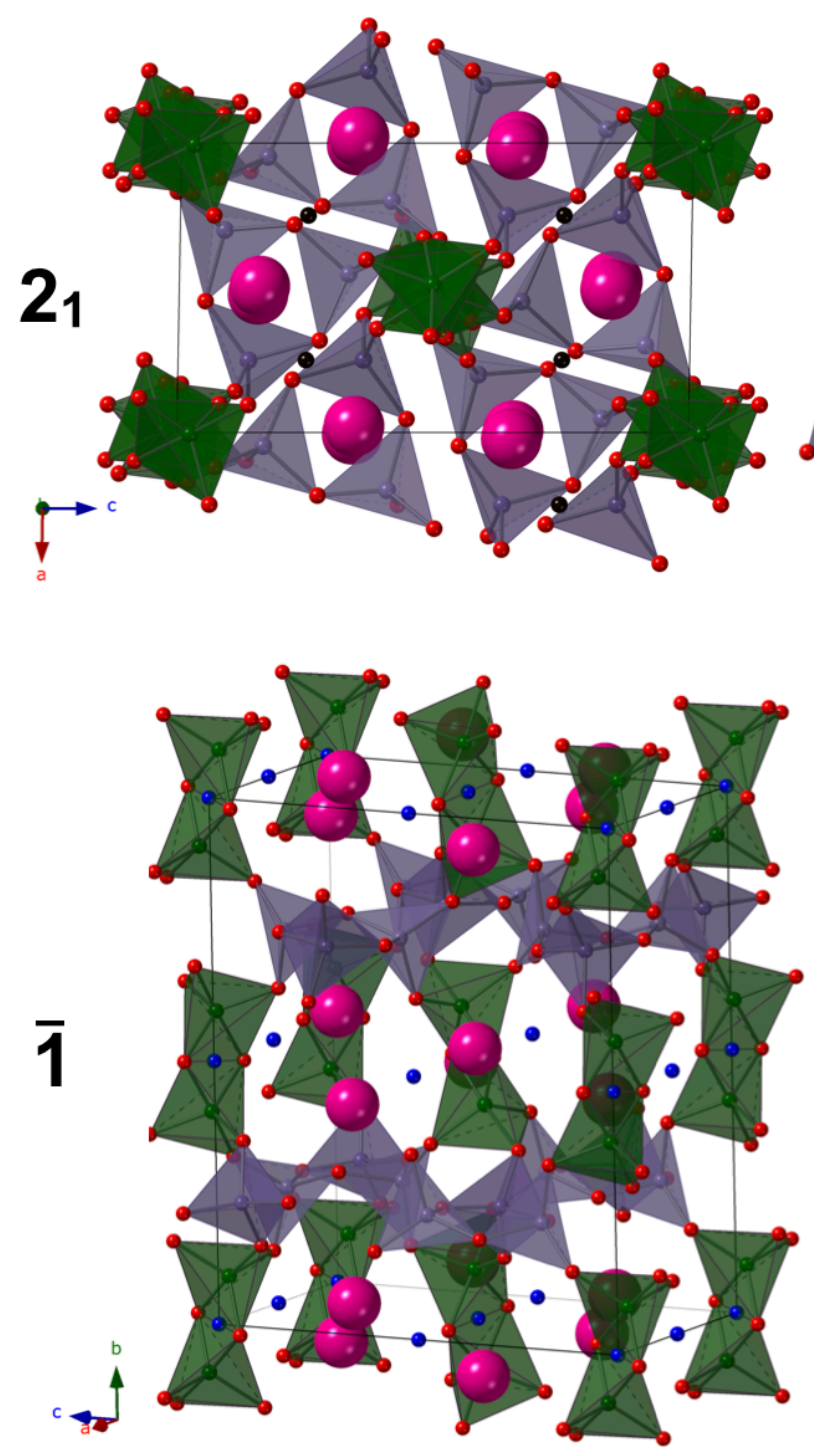

Rietveld
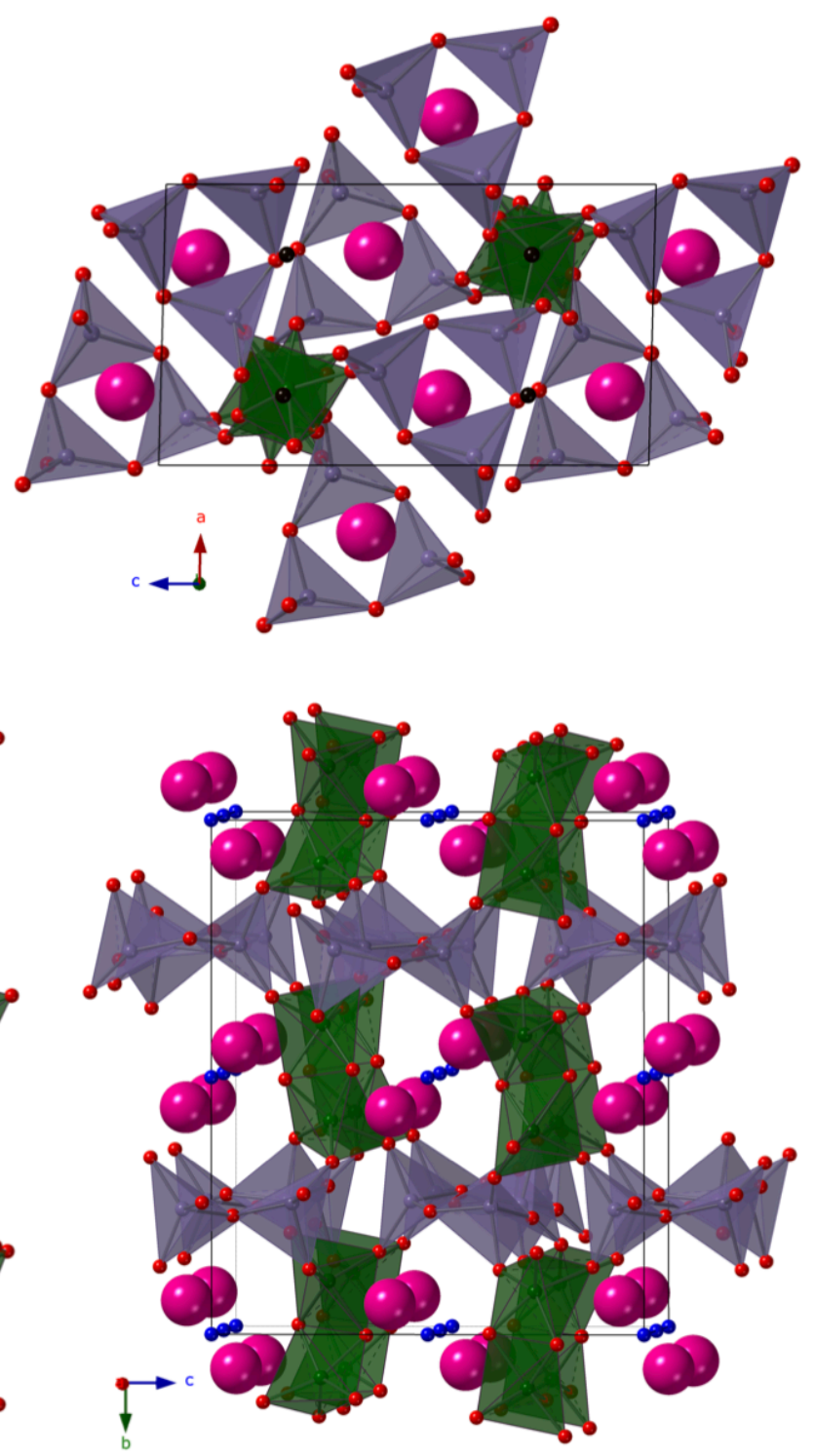

Figure S3. Structure of $\mathrm{Cs}_{2} \mathrm{Ge}_{5} \mathrm{O}_{11}$ as refined from SXRD data (left) and by Rietveld analysis of PXRD data (right) showing the $2_{1}$ screw axes (top - denoted by black cylinders) and the inversion centers (bottom - denoted by blue spheres). $\mathrm{GeO}_{4}$ polyhedra are shown in grey, $\mathrm{GeO}_{5}$ polyhedra in green, Cs atoms in pink, and oxygen atoms in red. 


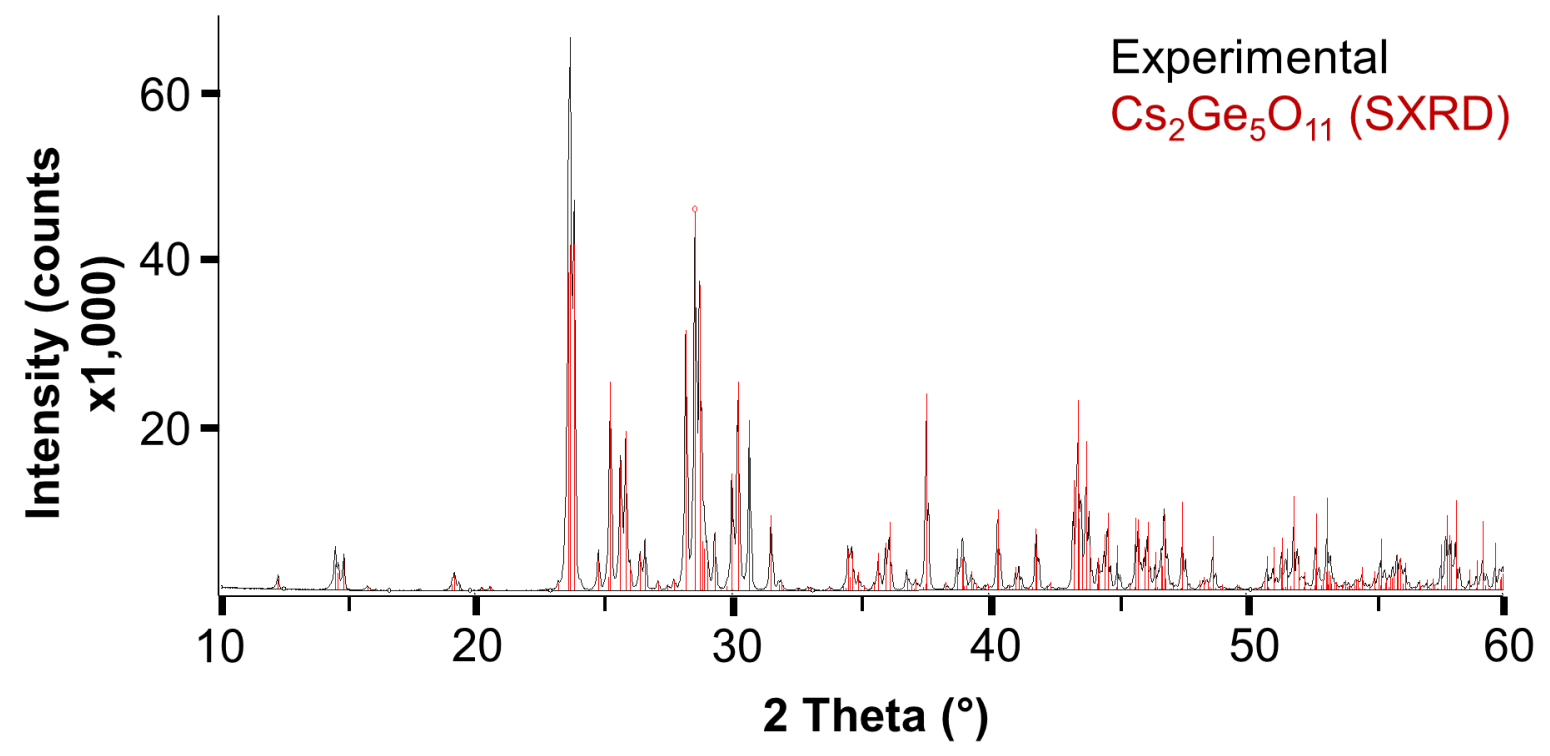

Figure S4. Powder X-ray diffraction pattern (black) and calculated pattern based on the SXRD model (red) for $\mathrm{Cs}_{2} \mathrm{Ge}_{5} \mathrm{O}_{11}$. 


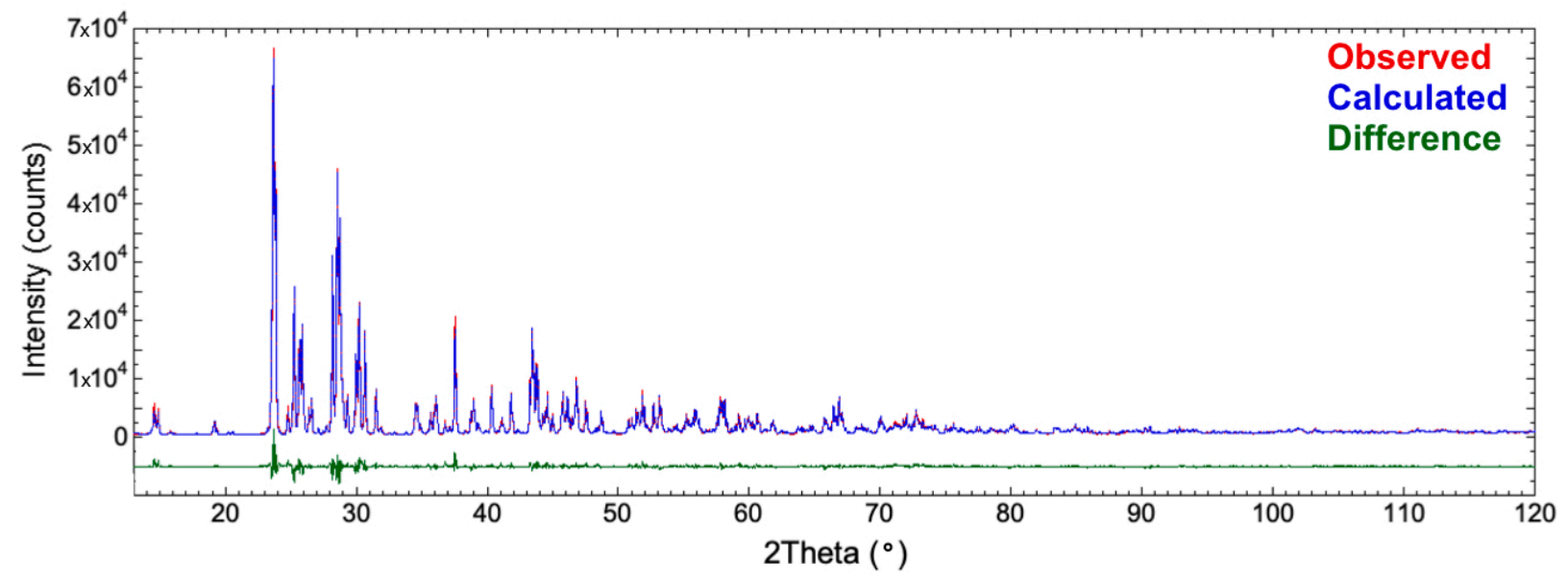

Figure S5. Rietveld refinement for $\mathrm{Cs}_{2} \mathrm{Ge}_{5} \mathrm{O}_{11}$ using the single crystal structure as a starting model. The difference pattern is offset by -5000 counts for easier viewing. 